\title{
污染地盤のバイオレメディエーションにおけるジオシンセティックスの適用
}

\author{
防衛大学校土木工学教室宮田喜壽, 木暮敬二 \\ (侏)フジタ技術センター技術研究所華获一郎，近藤敏仁，岡田正明，畠 俊郎
}

概要

污染地盤の修復技術として, エネルギ一消費量が小さいバイオレメディエーションが期待されている. しかし, 我が国の平野部に多く堆積している沖積粘土や火山灰質粘性土は一般に透気性や透水性が小さく， バイオレメディエーションの適用が困難となる. 本研究においては, バイオレメディエーションを粘性土 に対し適用する場合, 污染土の消石灰改良とジオシンセティックスの適用が有効であるという観点から, 石油系炭化水素による污染地盤の修復を対象に, 室内試験と模型実験を実施した. 本文では, 消石灰改良 とジオシンセティックスの適用を伴うバイオレメディエーションの基本的な概念を説明し, 本文で提案す る修復工法の実用化を検討するために実施した室内試験と模型実験の結果を示す.

キーワード : 複合ジオシンセティックス, フィルター, バイオレメディエーション, 目詰まり

\section{Application of geotextile filter for the bioremediation of contaminated ground}

\author{
National Defense Academy, Y. Miyata, K. Kogure \\ Fujita co., I. Kagaku, T. Kondo, M. Okada, T. Hata
}

\begin{abstract}
Today, there are a number of contaminated sites that have soils contaminated with oils and organic solvents. Bioremeidiation is one of the relatively few methods for actually destroying organic contaminants other than incineration and few chemical methods. In this study, in order to discuss the effective application method of the geotextile filters for the remediation system, laboratory test and model test were carried out. As a result, it was investigated that the effect of moving of soil particle and collection of $\mathrm{Ca}$ on the geotextile filter.
\end{abstract}

Keywords: geo-composite, filter, bioremediation, clogging 


\title{
污染地盤のバイオレメディエーションにおけるジオシンセティックスの適用
}

\author{
防衛大学校土木工学教室宮田喜壽, 木暮敬二 \\ 保フジタ技術センター技術研究所華䁨一郎，近藤敏仁，岡田正明，香 俊郎
}

\section{1.はじめに}

污染地盤の修復技術を開発する必要性が高まっている. 現在, 污染地盤の修復技術として, 原位置処理 や掘削土処理の方法がいくつか確立されているが, 低濃度の地盤污染の場合, エネルギ一消費量が小さい バイオレメディエーション（生物の機能を利用する環境污染の浄化技術の総称）が有力な修復技術として 期待されている ${ }^{1)}$ ，2．しかし，我が国の平野部に多く堆積している沖積粘土や火山灰質粘性土は一般に透 気性や透水性が小さい．このような地盤が長い年月を経て污染された場合，微生物の分解活動を維持する ために必要となる適当な水分や酸素, そして栄養塩を供給することが難しいために, バイオレメディエー ションの適用が困難となる。

本研究においては，バイオレメディエーションを粘性土に対し適用させるためには地盤環境をコントロ ールする必要があり, その場合污染土の消石灰改良とジオシンセティックスの適用が有効であるという観 点から, 石油系炭化水素による污染地盤の修復を対象に, 室内試験と模型実験を実施した。本文では, は じめに消石灰改良とジオシンセティックスの適用を伴うバイオレメディエーションの基本的な概念を説明 する. 次いで, バイオレメディエーションにおいて地盤内環境をコントロールする効果を室内の基礎実験 より明らかにする. そして最後に, 本文で提案する修復工法の実用化を検討するために実施した模型実験 の結果を示す.

\section{2. 消石灰改良とジオシンセティックスの適用を伴うバイオレメディエーション \\ 2. 1 技術の概要}

長い年月を経て炭化水素で污染された粘性土をバイオレメディエーションによって修復することは容易 でない，そこで，著者らは，污染した粘性土の透水性および透気性を消石灰改良によって改善し，修復系 に対する微生物と栄養塩, そして酸素の供給を, ジオシンセティックスを用いて行う修復工法を考えた. 本文で検討する修復工法の概要を図－1に示す，修復の手順は以下のとおりである．まず，污染した粘性 土を掘削して修復サイトに移動させ，そこで消石灰改良する．次に，ジオシンセティックスを用いながら ある程度の高さまで改良した污染土を盛り立てる，ここで，土中に敷設するジオシンセティックスには次 の3つの機能を期待する.（1）微生物と栄養塩, そして酸素を修復系に供給する，（2）污染土より構 成された盛土を安定化する，（3）ジオシンセティックス内に電熱線などを収め, 土中温度を一定の高さ に保つ. 以上の操作によって，小規模なヤードで比較的大量の污染土を修復できると考える. なお，消石 灰改良やジオシンセティックスの適用は原位置でも可能であるから，地下水の流れの制御に困難を伴わな い場合，以上の概念に基づく工法は污染サイトで直接的に適用できるとも考えている. 


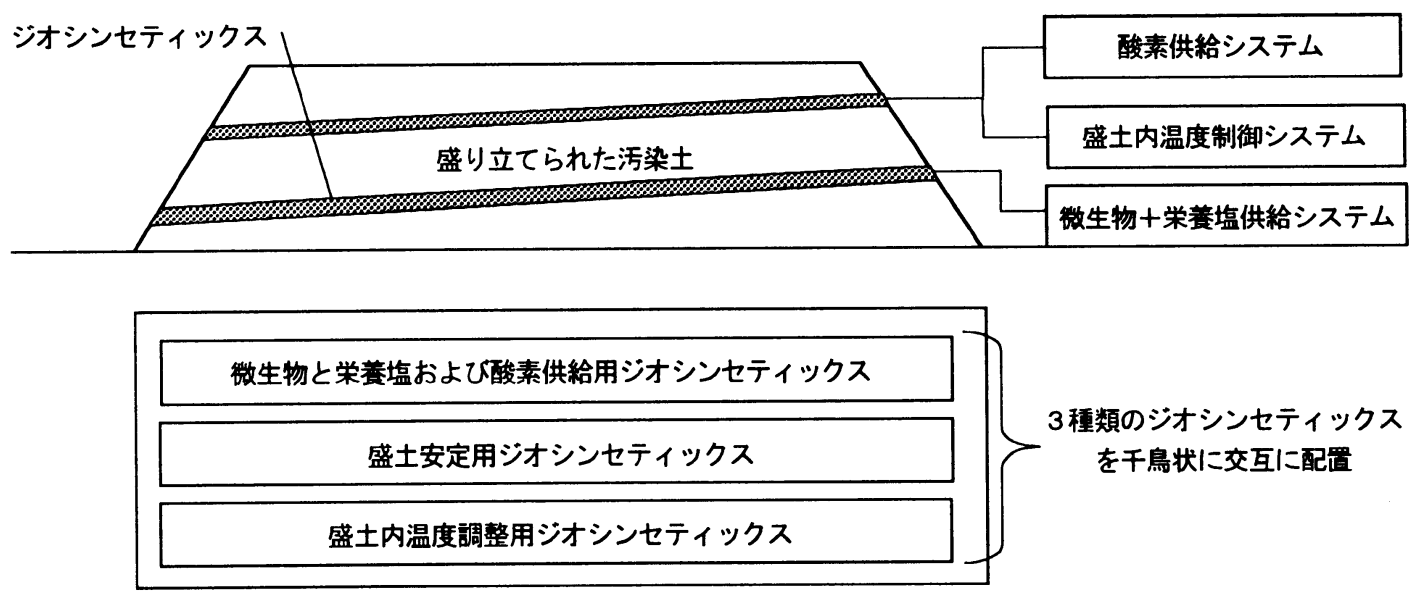

図一 1 消石灰改良とジオシンセティックスの適用を伴うバイオレメディエーション

\section{2 . 2 本修復工法の技術課題}

以上の工法の実用化に際しては種々の技術的課題がある. まず, 消石灰で改良を行うと, 污染土がアル カリ性を呈することになるので，アルカリ条件下で石油系炭化水素を分解する微生物を探索する必要があ ることである. この問題については, 著者らは別途検討を行い, 中性条件で炭化水素を分解する微生物と 同等の分解性能を有する微生物の分離に成功している ${ }^{3)}$. 他の課題としては, 炭化水素の分解過程で, 微 生物や栄養塩を供給する効果を確かめることと, ジオシンセティックス内部および表面の目詰まり特性お よび目詰まりに伴う面内方向通水性能の変化の影響について調べることが挙げられる.本論文においては, 以上の課題について検討するために室内試験と模型実験を実施した. 次章以降では，それらの結果につい て考察する.

\section{3. 炭化水素の分解過程で微生物と酸素を供給する効果}

\section{1 実験の概要}

\section{(1) 実験試料}

污染物質として想定する石油系炭化水素として軽油を用いた。 それをガスクロマトグラフィーと赤外分

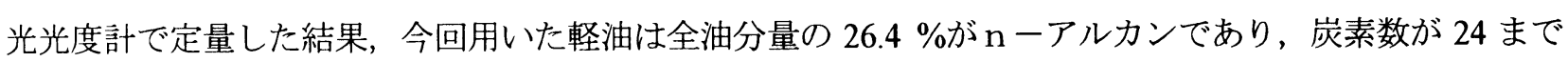
の $\mathrm{n}$ ーアルカンが含まれていることが分かった. 供試した微生物は活性污泥, 人工污染土, 魚水槽腐泥, 油田跡地土, 畑地土壤より分離したものの中から最も活性の高いものを用いた。

\section{（2）実験方法}

本実験の目的は, 初期の分解速度を維持するためには，石油系炭化水素の分解過程において，どのよう な補給が有効であるかを明らかにすることである．実験方法は以下のとおりである．まず，表一 1 に成分 を示した培地 $15 \mathrm{ml}$ を $125 \mathrm{ml}$ 容量のバイアル瓶に注入し, 軽油を濃度 $20000 \mathrm{mg} / 1$ になるように加え, 微生 物を植菌して密栓した. 次に, $25{ }^{\circ} \mathrm{C}, 160 \mathrm{rpm}$ の振とう培養を行い, 所定の日数ごとに分析試料を抜き取 った. 予備実験では, この条件において約 20 日間培養した後, 残留油分量の減少速度が緩慢になった. そ こで, 培養開始後 21 日目に表一 2 に示す 3 種類の補給を行い, 再び密栓して約 1 ヶ月間培養を継続し, そ 
表一 1 培地の成分

\begin{tabular}{|c|c|c|c|c|c|c|c|c|c|c|}
\hline $\begin{array}{c}\text { Hydro } \\
\text { carbon }\end{array}$ & $\mathrm{NH}_{4} \mathrm{Cl}$ & $\mathrm{K}_{2} \mathrm{HPO}_{4}$ & $\begin{array}{c}\mathrm{MgSO}_{4} \\
\cdot 7 \mathrm{H}_{2} \mathrm{O}\end{array}$ & $\begin{array}{c}\mathrm{CaCl}_{2} \\
\cdot 2 \mathrm{H}_{2} \mathrm{O}\end{array}$ & $\begin{array}{c}\mathrm{FeCl}_{3} \\
\cdot 7 \mathrm{H}_{2} \mathrm{O}\end{array}$ & $\begin{array}{c}\text { trace } \\
\text { mixture }\end{array}$ & $\begin{array}{c}\text { 酵母 } \\
\text { エキス }\end{array}$ & agar & $\mathrm{Na}_{2} \mathrm{CO}_{3}$ & D.W \\
\hline 所定量 & $0.5 \mathrm{~g}$ & $1.0 \mathrm{~g}$ & $0.2 \mathrm{~g}$ & $0.02 \mathrm{~g}$ & $0.05 \mathrm{~g}$ & $1.0 \mathrm{ml}$ & $0.01 \mathrm{~g}$ & $20 \mathrm{~g}$ & $10 \mathrm{~g}$ & $1000 \mathrm{ml}$ \\
\hline
\end{tabular}

trace mixture : 微量元素の濃縮混合液, agar：生物実験用の寒天 D.W. : 蒸留水

表一2 補給した微生物と栄養塩そして水の構成

\begin{tabular}{|c|l|}
\hline 微生物 & $10^{9}$ cells $/ \mathrm{ml}$ の微生物濃度の溶液 $1 \mathrm{ml}$ \\
\hline 栄養塩 & 窒素と塩類の濃度が表 -1 に成分を示した培地の 15 倍を有する溶液 $1.0 \mathrm{ml}$ \\
\hline 水 & 滅菌水 $10.0 \mathrm{ml}$ \\
\hline
\end{tabular}

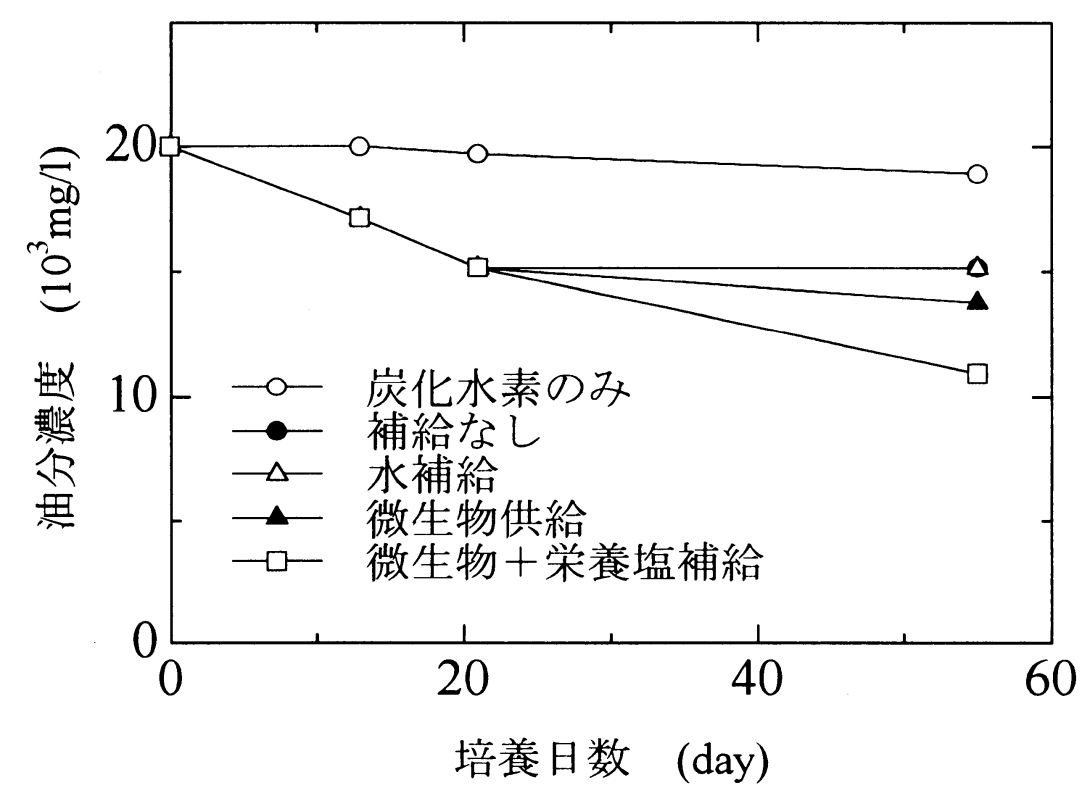

図-2 分解途中での微生物，栄養塩，水の補給効果

の後全油分量を計測することで，効果的な補給方法を検討した。

\section{2 実験結果と考察}

残留炭化水素濃度の推移を図一 2 に示す．培養開始後 20 日までの油分分解濃度は約 $11.0 \mathrm{mg} / 1 \mathrm{hr}$ を示し た. 21 日目に表一 2 に示寸各補給を行った後, 微生物と塩類を補給したケースについては当初の分解速度 を維持することができた. しかし，微生物のみを補給したケースでは，補給後の分解をほとんど進めるこ とはできなかった．培養 55 日後におけるアルカンの残留状況を図一3に示す．炭素数が 20 を超える炭化 水素については, 各ケースの差はほとんどない. しかし, 炭素数が 17 以下の炭化水素においては, 微生物 と塩類を補給したケースでの分解が顕著に認められる．以上のことから，分解過程において微生物と栄養 塩を定期的に補給すると，污染物質の速やかな分解が可能になることが分かった。 


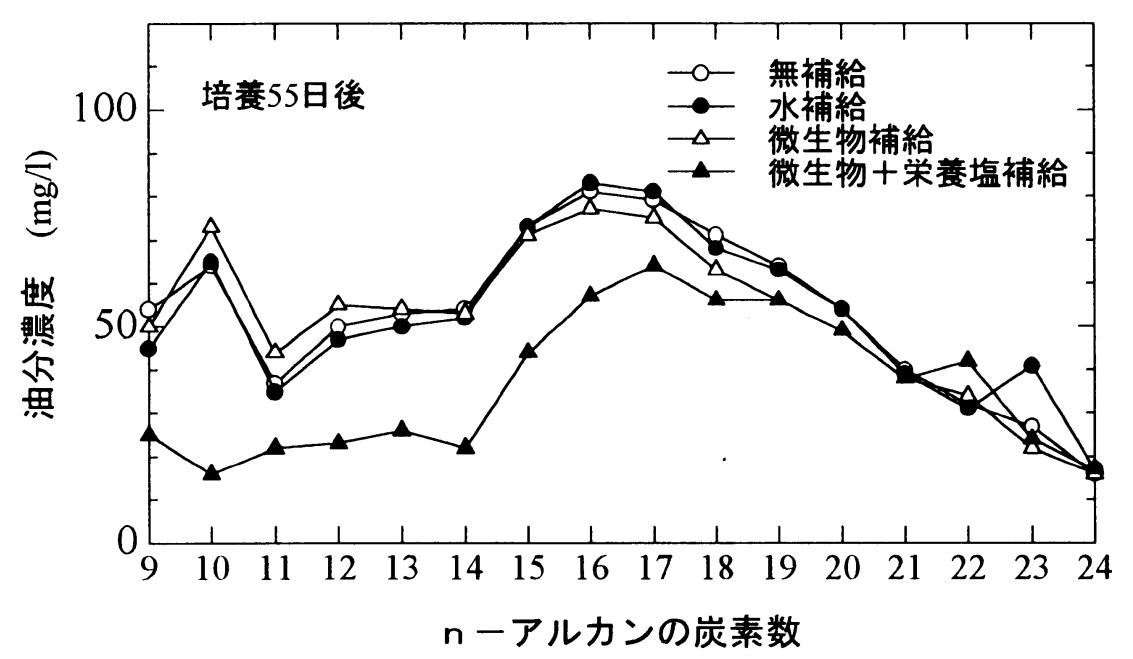

図一 3 微生物や栄養塩そして水補給後の $\mathrm{n}$ ーアルカン残留状況

\section{4. 模型実験の結果と考察}

\section{1 模型実験の概要}

\section{(1) 実験装置}

実験装置を図一 4 に示す，装置は， 人工污染土の修復を行う土槽と土槽内 に微生物と栄養塩の水溶液を供給する ための水循環装置, 土槽内に酸素を送 り込むための空気循環装置, 土槽内の 温度を一定の高さに保つためのヒータ 一および断熱層, 土槽内の水分と温度 の変化をモニタリングするための各種 計測器から構成される. 水循環装置お よび空気循環装置は，ロータリータイ マーを用いて自動制御した。

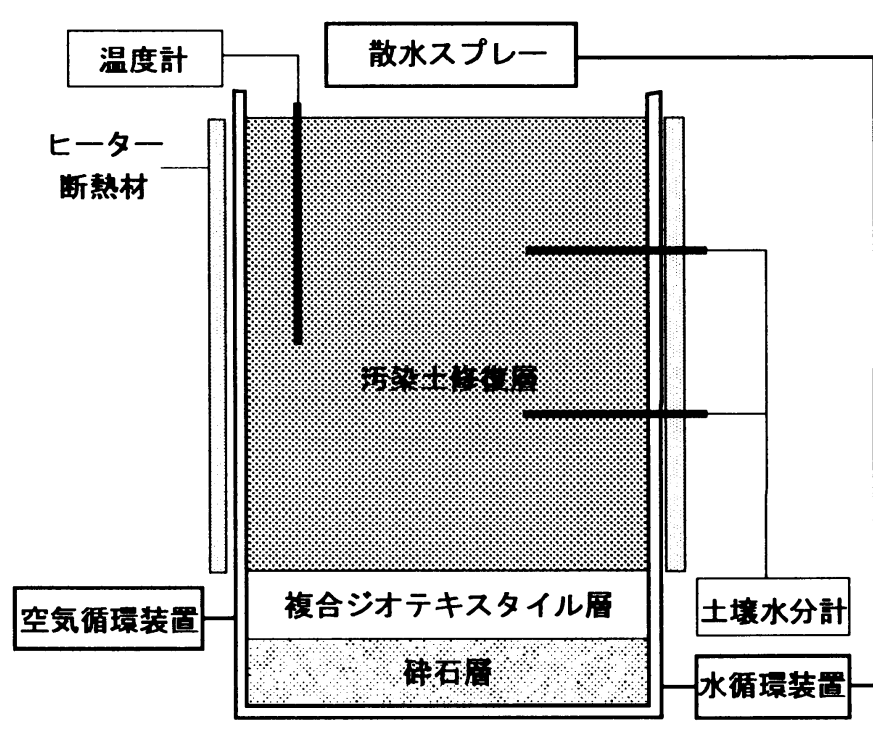

図-4 模型実験装置

\section{(2) 実験試料}

山梨県上野原に堆積していた表層の火山灰質粘性土（自然含水比 $100 \%$ ）を採取し，軽油を $5000 \mathrm{mg} / 1$ となるように添加して，人工污染土を作製した。供した複合ジオシンセティックスは，写真一 1 に示すよ うにへチマ状の硬質な心材を薄手の不織布で挟んだ製品であり，供した砕石は， $40 \mathrm{~mm}$ 以下に粒度調整さ れたものである。

\section{（3）実験方法}

(2)に述べた方法で作製した人工污染土を消石灰で処理したあと（消石灰の添加率は重量比にして $5 \%$ ）， 砕石をまきだし，複合ジオシンセティックスを敷設した後，人工污染土を 3 回に分けてドラム缶に投入し 
た. そして，1回の投入ごとに栄養塩水溶液（表一 1 に示した培地とほぼ同じ物質構成もの）3L と微生物 懸濁液（好アルカリの石油分解微生物と軽油馴養液） 2L をジョウロで散布した. 次に, 微生物と栄養塩の 水溶液を定期的に循環させるための水循環装置, 酸素 を土槽内に定期的に送り込むための空気循環装置, 温 度計，土袞水分計を取り付けた。 2. では温度調整に もジオシンセティックスを用いることを述べたが，そ れについては今後の検討課題とし, 土槽の温度を一定 に保つためのヒーターおよび断熱材をドラム缶に巻き つけ浄化を開始した. 浄化途中においては，土槽内温

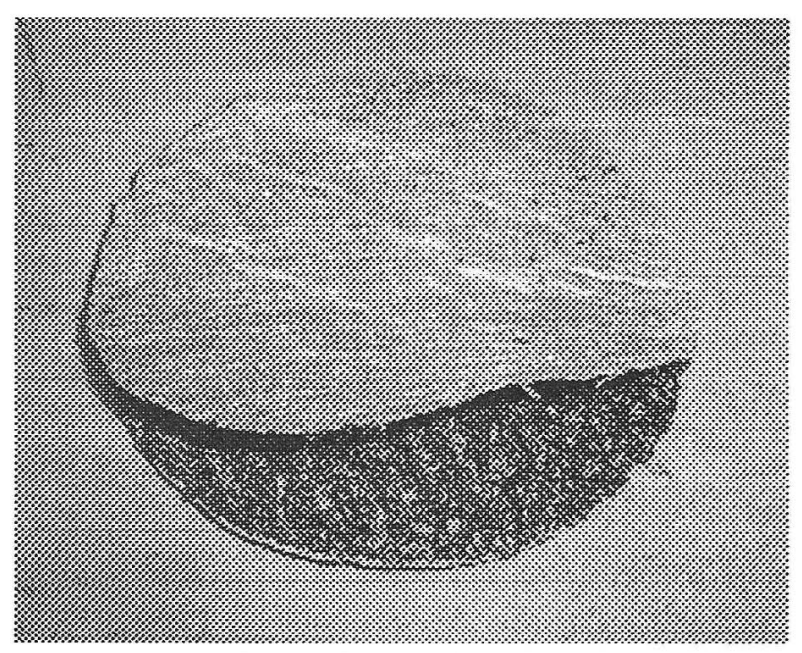

写真一 1 供した複合ジオシンセティックス 度と含水比, 循環水の $\mathrm{pH}$ およびリン・窒素濃度, 排 出量を定期的に測定しながら, 微生物と栄養塩を水循環装置を用いて修復系に供給した。 その後. 浄化開 始後 160 日目に土槽を解体して, その時点で土槽内の温度, 含水比, 単位体積重量, pHの分布を測定し, さらに複合ジオシンセティックスの変化, $\mathrm{n}$ ーアルカンの除去率を評価した.

\section{2 実験結果と考察}

\section{(1) 土槽内の状態}

土槽解体時に土槽内 12 点（鉛直方向 4 段階, 平面方向 3 点）で測定した温度, 含水比, 単位体積重量, $\mathrm{pH}$ を表一3に示す. なお，土槽内の各位置の説明は表の右側に示した図のとおりである. 使用したヒータ 一の性能のために，土槽全体を同じ温度に保つことはできなかったが，実験を冬季に実施したにもかかわ

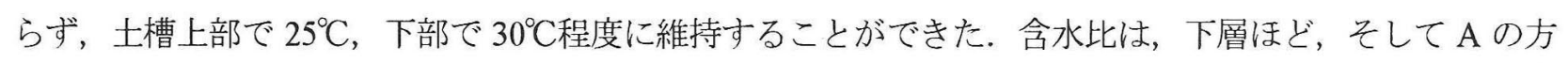
向ほど高い傾向を示したが, 単位体積重量はほぼ一定の值が計測された。 $\mathrm{pH}$ は含水比の高い地点ほど大き な值を示す傾向が認められた。

\section{(2)浸透に伴う細粒径土粒子の移動}

上部から微生物と栄養塩を浸透させるので, 細粒径の土粒子が下層に移動し, 複合ジオシンセティック ス表面を目詰まりさせる危険性がある. そこで, 土槽解体時に表一 3 の右図中 B-1〜 4 で表される 4 点にお いて試料を採集し，粒度分析を行った，結果を図一 5 に示寸。この結果より，例えば $20 \%$ 粒径に着目する と，その值は下層ほど小さくなることが分かる．净化開始前はほぼ同一の粒度分布を示していたと考えら れ，この違いは浸透に伴う細粒径の土粒子の移動によってもたらされたと考えることができる. また, 細 粒径の土粒子の構成比が大きくなった下層ほど士の保水性が高まったために, 表一3に示した含水比分布 が生じたと考えられる. 図一6では，4層の平均の粒度分布と消石灰改良前の人工污染土の粒径分布を比 較した.ここで50\%粒径に着目すると，消石灰改良によって，50\%粒径が大きくなっていることが分かり， その分土槽全体に微生物と栄養塩を均一に供給しやすい環境に近づけることができたことが分かる. 
表一3 土槽内の温度, 含水比, 単位体積重量, $\mathrm{pH}$ の分布

\begin{tabular}{|c|c|c|c|}
\hline \multirow{2}{*}{} & \multicolumn{3}{|c|}{ 温度 $\left({ }^{\circ} \mathrm{C}\right) /$ 含水比 $(\%) /$ 単位体積重量 $(\mathrm{g} \cdot \mathrm{cm}-3) / \mathrm{pH}$} \\
\cline { 2 - 4 } & $\mathrm{A}$ & $\mathrm{B}$ & $\mathrm{C}$ \\
\hline 1 & $26 / 126 / 1.37 / 8.9$ & $19 / 121 / 1.32 / 9.4$ & $18 / 121 / 1.35 / 10.8$ \\
\hline 2 & $36 / 127 / 1.34 / 9.8$ & $28 / 126 / 1.23 / 11.0$ & $26 / 125 / 1.22 / 10.9$ \\
\hline 3 & $37 / 125 / 1.35 / 10.5$ & $31 / 124 / 1.28 / 11.1$ & $28 / 126 / 1.25 / 10.7$ \\
\hline 4 & $34 / 132 / 1.32 / 11.2$ & $31 / 133 / 1.27 / 11.2$ & $29 / 118 / 1.33 / 10.9$ \\
\hline
\end{tabular}

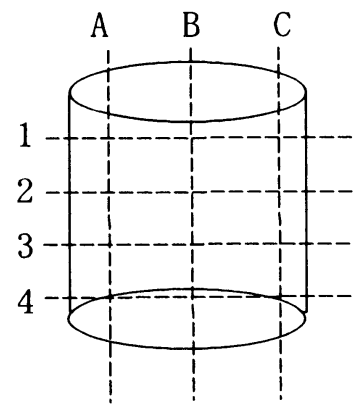

(3) 複合ジオシンセティックスの変化

土槽解体後, 修復土の下に配置した複 合ジオシンセティックス表面には，図一 7に示すな位置に白い析出物が確認され た. その析出物の元素組織の分析結果を 図一8に示す。析出物の大半はカルシウ ムであり，消石灰の成分が複合ジオシン セティックス表面に析出されたと考えら れる．本実験では，ヒーターの性能のた めに，Aの方向ほど土中温度が高い傾向 にあった。そのことが，複合ジオシンセ ティックス表面に析出物を生じさせた要 因になったと考えられる，また，複合ジ オシンセティックス表面の析出状況をみ ると，その部分の透気性および透水性は ほぼゼロの状態に変化していたであろう ことが予測でき，このこともその周辺の 含水比が高くなった要因になったと考え られる. 今後, このようなメカニズムで 生じる目詰まりについて詳しく調べる予 定である.

\section{(4) $n$ ーアルカンの除去率}

最後に, $\mathrm{n}$ ーアルカンの除去率の分布 を表一 4 に示す． $\mathrm{n}$ ーアルカンの除去率

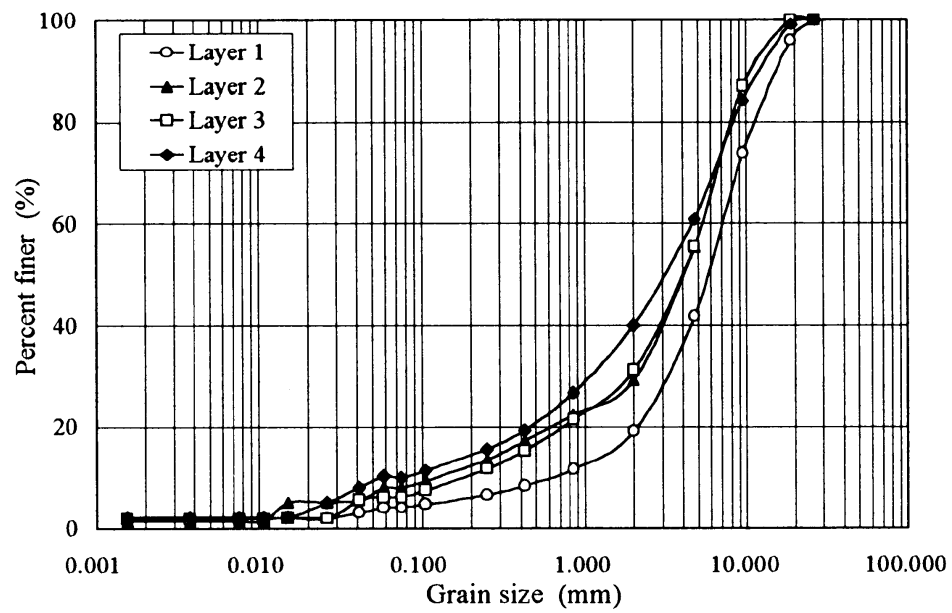

図－5 160 日浄化後の土槽内における粒度分布の違い

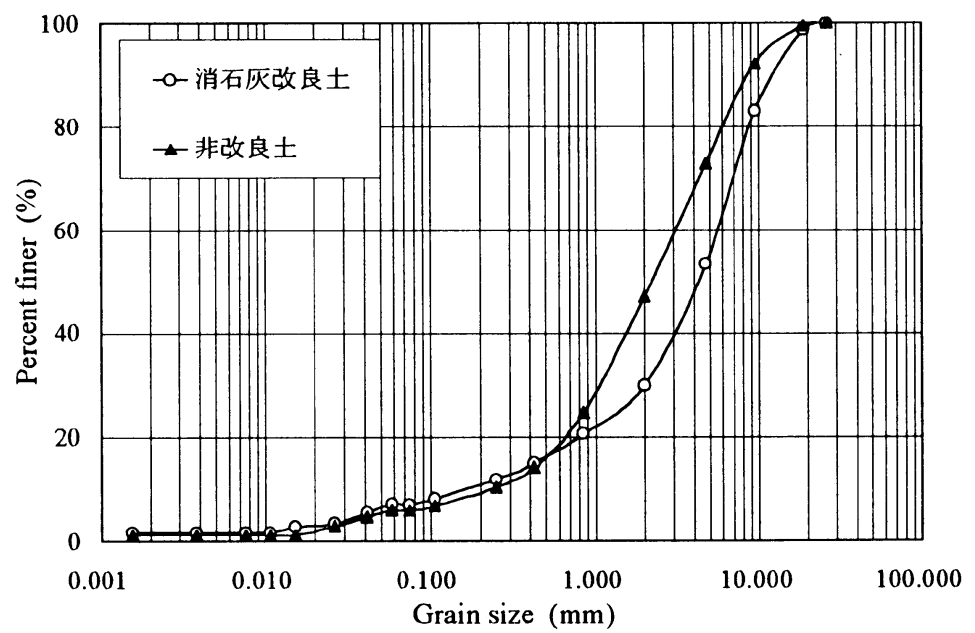

図-6 消石灰改良の効果 は表層ほど高い值を示しており，この実験結果からみると，有効修復媣さは土槽表面から $30 〜 40 \mathrm{~cm}$ であ ったと評価できる.現段階において，以上(3)に示した複合ジオシンセティックス表面の目詰まりの問題が $\mathrm{n}$ ーアルカンの除去率に及ぼした影響を定量的に評価することはできない，ただ，3つの効果を期待して （参照 : 図一1），修復土からなる盛土内にジオシンセティックスを配置する場合，その配置間隔の決定 には本文に示した実験結果をふまえ検討する必要があると考える. 


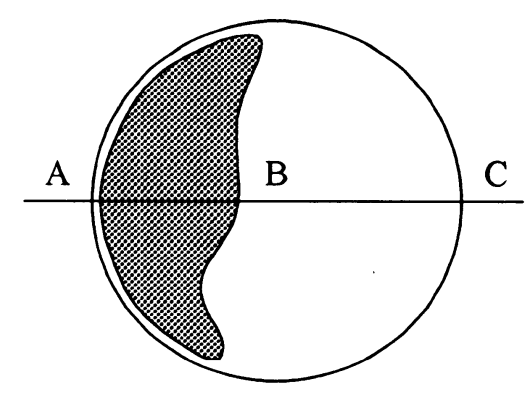

複合ジオシンセティックス表面 で白色の物質が析出した領域

図一 7 修復開始 160 日後の

複合ジオシンセティックス

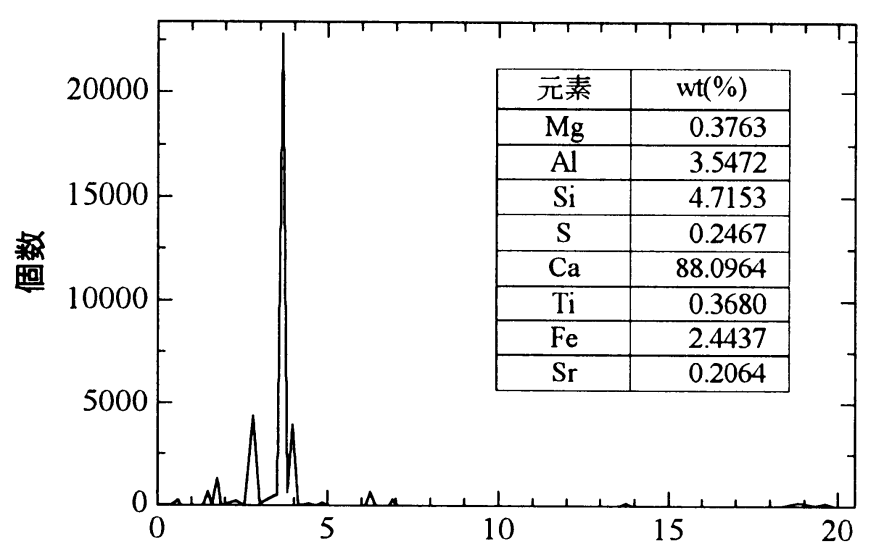

電圧 $(\mathrm{keV})$

図－8＼cjkstart複合ジオシンセティックス表面の析出物の解析

表一４各地点での $\mathrm{n}$ アルカンの除去率（\%)

\begin{tabular}{|c|c|c|c|}
\hline & A & B & C \\
\hline 1 & 74 & 65 & 65 \\
\hline 2 & 76 & 41 & 44 \\
\hline 3 & 71 & 38 & 21 \\
\hline 4 & 24 & 15 & 12 \\
\hline
\end{tabular}

\section{5. まとめ}

本論文に示した内容は以下のようにまとめられる.

(1) 消石灰改良とジオシンセティックスの適用を組み合わせたバイオレメディエーションの考え方を示し た。この工法では，修復系に微生物と栄養塩そして酸素を供給する，污染土で構成される盛土を安定 化する, 修復系を一定の温度に保つという3つの効果を期待して, ジオシンセティックスを適用する.

（2）分解過程において微生物と塩類を定期的に補給すると，污染物質の速やかな分解が可能になることを 室内試験の結果より示した。

(3) $2 \mathrm{~m}^{3}$ 程度の人工污染土を用いた模型実験より, 消石灰改良とジオシンセティックスの適用を伴うバイ オレメディエーションがある程度の実用性を有していることを示した。一方，その技術は複合ジオシ ンセティックス表面でのカルシウムの析出などの課題を有していることも示した.

\section{参考文献}

1) Flathman,P.E. et al. : Bioremediation Field Experience, Lewis Publishers, 1994.

2) Brubaker,G.E. : In-situ bioremediation: how has it changed in the past 20 years? How will it change in the next 10?, Proc. of Geoenvironment 2000, Published by ASCE, Vol.2, pp.1437-1455, 1995.

3）木暮敬二・宮田喜壽・近藤敏仁, 岡田正明 : 石油系炭化水素污染土の改良を伴うバイオレメディエー ションに関する基礎的研究，土と基礎，47-10, pp.5-8, 1999. 